DOI: $10.31393 /$ reports-vnmedical-2019-23(1)-15

UDC: $611.37 .018 .1+[616.37-018.1-053.13: 616-097.1] .08: 599.323 .45$

\title{
DYNAMICS OF DISTRIBUTION WGA+ RECEPTORS IN PANCREAS IN NORM AND AFTER INTRANATAL ACTION OF ANTIGENS
}

Grynivetska N.V., Hryhorieva O.A.

Zaporozhye State Medical University (Mayakovsky avenue, 26, Zaporizhzhya, Ukraine, 69035)

Received 4 January 2019 p.; Accepted 4 February 2019 p.

Responsible for correspondence: e-mail: nataliagrin7@gmail.com

\begin{abstract}
Annotation. Study of features of expression of carbohydrate bits (receptors to lectins) on the surface of cells, in the contests of intracellular granules and on components of extracellular matrix allows to widen the understanding of processes of organs morphogenesis and fabrics and understand the features of reactivity in reply to the action of various factors in the antenatal period of development. Research aim - to set the features of distribution and dynamics of expression of receptors to the wheat germ agglutinin (WGA) in the structures of pancreas in a norm and after the intranatal action of antigens. 126 pancreases of white laboratory rats from a moment birth to ninetieth time of postnatal life were examined in the research work. Rats were retained in a vivarium according to corresponding recommendations. The investigated animals were divided into three groups. The first group is intact rats; the second are control rats, the third are rats, what were undergone intranatal injection of Vaxygrip vaccine. During work with experimental animals followed European convention for defense of vertebrates that are used in experimental and other scientific aims (Strasbourg, 18.03.86). Exposure of carbohydrate bits and pieces of $\mathrm{N}$-acetyl-D-glucosamine in microsections was conducted with application of wheat germ agglutinin (WGA), drawing on the standard set of lectins of SEC "Lectintest" (Lviv). Intensity of deposit of benzidine mark was estimated semi-quantitative. It is set that for experimental animals regardless of way of introduction to the antigen is observed increase of closeness of distribution of carbohydrate bits and pieces of $N$-acetyl-D-glucosamine in all investigated structures, most expressive in the wall of channels and vessels. Fastening of zymogenic granules of pancreatic exocrine cells acinus with bits and pieces of carbohydrate of $\mathrm{N}$-acetyl-D-glucosamine testifies, that converting of proenzyme into an active form takes place at participation of glycopolymers. As carbohydrate determinants enter in the complement of zymogenic granules of pancreatic exocrine cells, the educed increase in an amount receptor to the lectin of embryos of wheat can influence on composition and properties of enzymes that is synthesized in acinar cells.
\end{abstract}

Keywords: pancreas, lectin of embryos of wheat, acinar cells, intrafetal introduction to the antigen.

\section{Introduction}

The deterioration of the ecological state in Ukraine, the influence of various factors on the body of the pregnant woman leads to an increase in perinatal pathology [4]. Antenatal antigenic load on the mother-placenta-fetus system promotes the formation of a syndrome of undifferentiated connective tissue dysplasia [2], which is characterized by manifestations from all systems of the body, including the digestive system [5]. Numerous diseases of the digestive system in general and the pancreas, in particular in children and adults, are associated with intrauterine development, therefore, the expansion of anatomical studies of the pancreas in the perinatal period of development is an urgent necessity [6]. An important role in understanding the processes of morphogenesis play the lectins, which are recognized as informative molecular probes that identify the glycoconjugates of cells and tissues, to study their dynamics in physiological and pathological conditions [3]. Glycoconjugates are the main components of the outer surface of the cell. Their carbohydrate structure is irreversibly changing in the process of development. Lectins and their receptors provide intercellular, cellular-matrix interactions, participate in the regulation of processes of proliferation, differentiation and apoptosis of cells. The study of the features of the expression of carbohydrate residues (lectin receptors) on the cell surface, consisting of intracytoplasmic granules and components of the extracellular matrix, allows to deepen understanding of the processes of morphogenesis of organs and tissues and to understand the features of reactivity in response to the action of various factors in the fetal development period.

The purpose of the study is to determine the peculiarities of the distribution and dynamics of receptor expression to lectin of wheat germs in pancreatic structures in normal and after intranatal action of antigens.

\section{Materials and methods}

The subjects of the study were 126 pancreas of white laboratory rats from the time of birth to the ninety days of postnatal life, which were kept in vivarium according to the relevant recommendations. The animals under investigation were divided into three groups, in each there were by 42 animals. The first group - intact rats. The second group - control rats, were injected with $0.05 \mathrm{ml}$ of physiological solution. The third group - the rats, were injected intranatally into the inter-shovel part of $0.05 \mathrm{ml}$ of inactivated split vaccine, Vaksigrip, diluted in equal volumes (1:1) with physiological solution. Intranatal administration of antigens and physiological solution was carried out operatively by the method of M. A. Voloshin. For this on 18 days after fertilization, pregnant females under anesthesia performed medial laparotomy, adhering to the rules of 
asepsis and antiseptics. The fetuses were through-utero, through-shell, subcutaneously into the inter-shovel region, $0.05 \mathrm{ml}$ of the corresponding solution was injected. Birth came on 22-23 days after fertilization. Animals were extracted from the experiment on days 1, 7, 14, 21, 45 and 90 of the postnatal life. When working with experimental animals, the European Convention for the Protection of Vertebrate Animals used for experimental and other scientific purposes was guided (Strasbourg, March 18, 1986).

The pancreas was fixed in Buen's fluid. Dehydration in the ascending battery of alcohols began with 40-degree ethanol. Paraffin blocks were made. Histological slices were made in a thickness of 4 microns. Detection of carbohydrate residues of $\mathrm{N}$-acetyl-D-glucosamine (GIcNAc) was carried out using wheat germ lectin (WGA) using standard sets of lectins NVC "Lectintest" (Lviv). The intensity of the deposit of the benzidine label was evaluated in a semi-quantitative manner in "+": +++ is dark brown, ++ is brown, + is light brown, \pm is beige color; - - no reaction. Intermediate shades of colors were evaluated accordingly: $++/+++/ ;+/++$, and so on.

\section{Results. Discussion}

$\mathrm{N}$-acetyl-D-glucosamine and sialic acid are the terminal carbohydrate residues of the wheat germ lectin receptors. Investigation of the characteristics of the distribution of receptors to lectins of wheat germs in the structures of the pancreas allows us to study the functional state of acinocytes, since the transformation of the pro-enzyme into the active form occurs with the participation of glycopolymers [1].

On the first day of life in the intact and control group of animals, the most intensive WGA + receptors are distributed in the capsule of the pancreas, in the wall of the ducts and walls of the blood vessels, painted in the intermediate between brown and light brown $(++/+)$. The extracellular matrix of the interstitial connective tissue contains a small number of $\mathrm{N}$-acetyl-D-glucosamine residues, which is shown with less intensity of coloration. Acinar cells have a different degree of distribution of WGA + receptors: in the basal cell, intra-cytoplasmic granules exhibit greater expression of the WGA + receptors than in the apical part; this is manifested by a more intense coloration of the basal part $(++/+)$ and smaller - the apical part of the acinocytes $(+)$.

In newborn animals, which were introduced intranatally antigen, the number of WGA+ substances increase in all investigated structures. The capsule, the wall of ducts and vessels are brown (++), connective tissue is light brown $(+)$. In acinocytes, the residues of $\mathrm{N}$-acetyl-D-glucosamine are distributed unevenly, the basal part of the cells contains a large number of them and is brown (++), and the apical part of the acinocyte binds less amount of carbohydrate residues and is painted in an intermediate shade of brown to light brown color (+).
On the seventh day after the natal life in intact and control animals, the unchanged amount of carbohydrate residues $\mathrm{N}$-acetyl-D-glucosamine and sialic acid in the capsule of the gland, the walls of blood vessels and ducts, as well as acinar cells is observed in comparison with the third day of life. In the connective tissue, the number of receptors increases slightly compared with the first and third observation days and is colored in light brown color (+). In the group of antigen-primed animals with intranatal administration of the vaccine, there is a tendency to increase the density of receptor distribution to wheat germs in all investigated structures, except connective tissue.

On the fourteenth day of life of animals in the group of intact and control animals in the pancreatic capsule, the distribution density of the WGA+ receptors, which are painted in an intermediate shade from brown to light brown, remain at the seventh day of observation. The intensity of the coloration of the extracellular matrix of the connective tissue also does not change. The wall of the blood vessels and ducts in this observation period contains a large number of carbohydrate residues of $\mathrm{N}$-acetyl-Dglucosamine and sialic acid and is brown in color. Acinar cells, while maintaining the uneven distribution of the WGA+ receptors, remain in the intermediate shade from brown to light brown in the basal part and light brown in the apical part of the cell.

In experimental animals, the distribution density of the WGA+ receptors in the pancreatic capsule and in the extracellular matrix of the connective tissue remains at the seventh day of observation compared to control and intact rats. Duct walls and blood vessels contain more WGA+ receptors than the first week of observation and are painted in an intermediate shade of brown to dark brown. The cells of the exocrine part on the carbohydrate residues content of $\mathrm{N}$-acetyl-D-glucosamine and sialic acid remain at the level of the pre-term observation period.

From the twenty-first day of life in animals of the intact and control groups in the pancreatic capsule, the accumulation of the benzidine label increases to brown color (++). There is no change in the extracellular matrix of the connective tissue and the walls of the blood vessels. The pancreatic duct wall increases the amount of carbohydrate residues of $\mathrm{N}$-acetyl-D-glucosamine and sialic acid and is painted in an intermediate shade of brown to dark brown (++ / +++). In acinar cells, the number of WGA-positive receptors remains unchanged relative to the previous observation period. In the group of experimental animals, there is also a tendency to increase the carbohydrate residues of $\mathrm{N}$-acetyl-D-glucosamine and sialic acid in the capsule of the pancreas, in the walls of the ducts and walls of the blood vessels. The connective tissue and acinar cells contain the same number of receptors for lectin of wheat germs as in the fourteenth day of life. Acinar cells leave uneven distribution of receptors: in the basal part, the cytoplasmic inclusions have a brown color, in the apical section a light brown color. 
On the forty-fifth day of life in the group of intact and control rats there is a decrease in receptor density to lectin of wheat germ capsules, in the walls of ducts and blood vessels. In the acinar cells of the lobules, reduction of the carbohydrate residues of $\mathrm{N}$-acetyl-D-glucosamine and sialic acid in the apical part of the cells $( \pm)$ can be noted, with the preservation of a greater number of receptors in the basal part $(+)$. In a group of experimental animals, the density of receptor distribution in the pancreatic capsule also decreases compared to the animals of the twentyfirst day of life. The connective tissue on the accumulation of the benzidine label remains at the level of the intact and control groups, but decreased relative to the previous observation period. The walls of the ducts are brown and the number of receptors corresponds to the intact and control groups. The wall of blood vessels on the level of expression of the receptors to lectin of wheat germs remains at the level of the intact and control groups. Acinar cells on the density of receptor distribution to lectin of wheat germs also do not differ from intact and control animals.

On the ninetieth day of life, compared with the forty-fifth day in intact and control animals, there is a tendency to reduce the expression of WGA-positive receptors in the pancreatic capsule, the wall of the blood vessels and ducts in relation to the pre-term observation period. In the connective tissue, the density of receptor distribution is minimal. In experimental animals, the density of the distribution of receptors to lectin of wheat germs in the capsule of the gland, connective tissue, ducts, blood vessel walls, and also in acinar cells coincides with intact and

\section{Список посилань}

1. Бархина, Т. Г., Донской, М. В., \& Савищев, А. В. (2008) Ультраструктура поджелудочной железы крыс линии Wistar albicans. Морфологические ведомости, 9-10.

2. Волошин, М. А., \& Григор'єва, О. А. (2011). Експериментальне моделювання недиференційованої дисплазії сполучної тканини шляхом порушення антигенного гомеостазу в системі мати-плацента-плід. Патологія, 8 (2), 39-42.

3. Волошин, Н. А., \& Григорьева, Е. А. (2005). Лектины животного и растительного происхождения: роль в процессах морфогенеза. Журнал АМН України, 11 (2), 223237.

4. Знаменська, Т. К., Воробьова, О. В., \& Дубініна, Т. Ю. (2018). Стратегічні напрямки реконструкції системи охорони здоровя новонароджених та дітей україни. Соціальна педіатрія та реабілітологія, 1-2 (13-14), 7-14.

5. Иванова, И. И., Гнусаев, С. Ф., Апенченко, Ю. С., Капустина, Л. В., Герасимов, Н. А., \& Солдатова И. А. (2012) Особенности проявлений заболеваний пищеварительного тракта у детей с дисплазией соединительной ткани. Вопросы современной педиатрии, 11 (5), 50-55.

6. Слободян, О. М. (2008). Гістотопографічні особливості панкреатодуоденального органокомплексу у плодів та новонароджених. Морфологія, 2 (4), 47-50.

\section{References}

1. Barkhina, T. G., Donskoy, M. V., \& Savischev, A.V. (2008). Ultrastructura podjeludochnoy jelezi kris linii Wistar albicans [Ultrastructure of pancreas of Wistar albicans rats]. Morfologicheskie vedomosti - Morphological digest, 9-10. control groups.

Thus, in experimental animals, regardless of the route of administration of the antigen, an increase in the density of the distribution of carbohydrate residues of N-acetyl-Dglucosamine in all investigated structures is observed, most pronounced in the wall of ducts and vessels. The binding of zymogenic granules of pancreatic acinius with carbohydrate residues, $\mathrm{N}$-acetyl-D-glucosamine, suggests that the conversion of pro-enzyme to the active form occurs with the participation of glycopolymers. Since carbohydrate determinants are part of the zymogenic pancreatic cell granules, an increase in the number of receptors to lectin in wheat germs can affect the composition and properties of enzymes synthesized in acinocytes.

\section{Conclusions and perspectives of further developments}

1. The distribution of carbohydrate residues ( $\mathrm{N}$-acetylD-glucosamine and sialic acid) in the structures of the pancreas is characterized by zonation.

2. In rats of experimental groups after intranatal administration of antigen, an increase in the accumulation of residues of $\mathrm{N}$-acetyl-D-glucosamine and sialic acid in the wall of ducts, vessels, capsules and acinar pancreatic cells from 1 to 14 days of life of animals was found, compared with the control group of observation.

In the future it is planned to establish morphological criteria for changes in the pancreas in animals with experimental undifferentiated dysplasia of the connective tissue.

2. Voloshyn, M. A., \& Hryhorieva, O. A. (2011). Experimentalne modeluvannya nediferentciyovanoy dysplasia spoluchnoy tkanini shlahom porushennya antigennogo homeostasu $\mathrm{v}$ systemi mati-placenta-plid [Experimental model of unclassified dysplasia of connective tissue by impairment of antigen homeostasis in mother-placenta -fetus system]. Patologia Pathology, 8 (2), 39-42.

3. Voloshyn, M. A., \& Hryhorieva, O. A. (2005). Lectini jivitnigi I rastitelnogo proischogdeniya; rol' $v$ processah morfogeneza [Plant and animal lectis: their role in morphogenesis processes]. Jurnal AMN Ukraini - Journal of AMS of Ukraine, 11 (2), 223237.

4. Znamenska, T. K., Vorobyeva, O. V., \& Dubinina, T. Yu. (2018). Strategichni napryamki rekonstruktcii systemi ohoroni zdorovya novonarodjenich ta ditey Ukraini [Strategic directions of reconstruction of the system of health guard of new-born and children of Ukraine]. Social'na pediatriya ta reabilitologiya Social paediatrics and rehabilitology, 1-2 (13-14), 7-14.

5. Ivanov, I. I., Gnusayev, S. F., Apenchenko, Yu. S., Kapustina, L. V., Herasimov, N. A., \& Soldatova, I. A. (2012).Osobennosti proyavleniy zabolevaniy pischevaritelnogotrakta $\mathrm{u}$ detey $\mathrm{s}$ dysplasiey soedinitelnoy tkani [Features of displays of digestive tract diseases in children with dysplasia of connective tissue]. Voprosi sovremennoy pediatrii - Questions of modern paediatrics, 11 (5), 50-55.

6. Slobodyan, O. M. (2008). Histotopografoanatomichni osoblivosti pancreatoduodenal'nogo komplekcu u plodiv ta novonarodjenich [Histotopographic peculiarities of pancreato-duodenal complex in fetus and newborns]. Morfologiya - Morphology, 2 (4), 47-50. 
ДИНАМІКА РОЗПОДІЛУ WGА+ РЕЦЕПТОРІВ У ПІДШЛУНКОВИЙ ЗАЛОЗІ В НОРМІ ТА ПІСЛЯ ВНУТРІШНЬОУТРОБНОї ДІЇ АНТИГЕНІВ

Грінівецька Н.В., Григор'єва О.А.

Анотація. Вивчення особливостей експресії вуглеводних залишків (рецепторів до лектинів) на поверхні клітин, у складі внутрішньоцитоплазматичних гранул та компонентів екстрацелюлярного матриксу дозволяє поглибити розуміння процесів морфогенезу органів і тканин та зрозуміти особливості реактивності у відповідь на дію різноманітних фракторів у внутрішньоутробному періоді розвитку. Мета дослідження - встановити особливості розподілу і динаміки експресії рецепторів до лектину зародків пшениці в структурах підшлункової залози в нормі та після внутрішньоутробної дії антигенів. Об'єктами дослідження стали 126 підшлункових залози білих лабораторних щурів від моменту народження до дев'яностої доби постнатального життя, яких утримували у віварії згідно з відповідними рекомендаціями. Досліджуваних тварин розділяли на три групи. Перша група - інтактні щури; друга - контрольні щури, третя - щури, яким внутрішньоплідно вводили інактивовану спліт-вакцину Ваксигрип. При роботі з експериментальними тваринами керувалися Європейською конвенцією з захисту хребетних тварин, які використовуються в експериментальних та інших наукових цілях (Страсбург, 18.03.86). Виявлення вуглеводних залишків N-ацетил-D-глюкозаміну (GlcNAc) у гістологічних зрізах проводили із застосуванням лектину зародків пшениці (WGA), використовуючи стандартний набір лектинів НВК "Лектинтест" (м. Львів). Інтенсивність відкладення бензидинової мітки оцінювали напівкількісно. Встановлено, що у експериментальних тварин незалежно від шляху введення антигену спостерігається збільшення щільності розподілу вуглеводних залишків $N$ ацетил-D-глюкозаміну в усіх досліджуваних структурах, найбільш виразне в стінці протоків та судин. Зв'язування зимогенних гранул панкреатоцитів ацинусів із залишками вуглеводу $N$-ацетил-D-глюкозаміну свідчить, що перетворення профрермента в активну форму відбувається при участі глікополімерів. Оскільки вуглеводні детермінанти входять до складу зимогенних гранул панкреатоцитів, виявлене збільшення в кількості рецепторів до лектину зародків пшениці може вплинути на склад та властивості фрерментів, що синтезуються в ациноцитах.

Ключові слова: підшлункова залоза, лектин зародків пшениці, ацинарні клітини, внутришньоплідне введення антигену.

\section{ДИНАМИКА РАСПРЕДЕЛЕНИЯ WGА+ РЕЦЕПТОРОВ В ПОДЖЕЛУДОЧНОЙ ЖЕЛЕЗЕ В НОРМЕ И ПОСЛЕ ВНУТРИУТРОБНОГО ДЕЙСТВИЯ АНТИГЕНОВ \\ Гринивецкая Н.В., Григорьева Е.А.}

Аннотация. Изучение особенностей экспрессии углеводных остатков (рецепторов к лектинам) на поверхности клеток, в составе внутрицитоплазматических гранул и компонентов экстрацеллюлярного матрикса позволяет расширить понимание процессов морфогеннеза органов и тканей и понять особенности реактивности в ответ на действие разнообразных фракторов во внутриутробном периоде развития. Цель исследования - установить особенности распределения и динамики экспрессии рецепторов к лектину завязи пшеницы в структурах поджелудочной железы в норме и после внутриутробного действия антигенов. Объектами исследования стали 126 поджелудочные железы белых лабораторных крыс от момента рождения до девяностых суток постнатальной жизни, которых содержали в виварии согласно соответствующим рекомендациям. Исследуемых животных разделяли на три группы. Первая группа - интактные крысы; вторая - контрольные крысы, третья - крысы, которым внутриплодно вводили иннактивированную сплит-вакцину Ваксигрип. При работе с экспериментальными животными руководствовались Европейской конвенцией по защите позвоночных животных, которые используются в экспериментальных и других научных иелях (Страсбург, 18.03.86). Выявление углеводных остатков N-ацетил-D-глюкозамина (GIcNAc) в гистологических срезах проводили с применением лектина зародышей пшеницы (WGA), используя стандартный набор лектинов НВК "Лектинтест" (ә. Львов). Интенсивность отложения бензидиновой метки оценивали полуколичественно. Установлено, что у экспериментальных животных независимо от пути введения антигена наблюдается увеличение плотности распределения углеводных остатков $N$-ацетил- $D$-глюкозамина во всех исследуемых структурах, наиболее выраженное в стенке протоков и сосудов. Связывание зимогенных гранул панкреатоцитов ацинусов с углеводными остатками $N$-ацетил-D-глюкозамина свидетельствует о том, что превращение профермента в активную фоору происходит при участии гликополимеров. Поскольку углеводные детерминанты входят в состав зимогенных гранул панкреатоцитов, выявленное увеличение количества рецепторов к лектину завязи пшеницы может повлиять на состав и свойства фрерментов, которые синтезируются в ациноцитах.

Ключевые слова: поджелудочная железа, лектин завязи пшеницы, ацинарные клетки, внутриплодное введение антигена. 